\title{
THE EFFECTIVENESS OF SCANNING AND SKIMMING IN IMPROVING READING COMPREHENTION SKILL OF MAHARANI NURSING STUDENTS
}

\author{
Chindy Hanggara Rosa Indah \\ Program Studi pendidikan Bahasa Inggris \\ IKIP Budi Utomo Malang \\ Jalan Citandui No 46 Malang \\ E-mail: chindyhanggara.ch@gmail.com
}

\begin{abstract}
Abstrak: Membaca merupakan salah satu cara mengajar Bahasa Inggris di Jurusan keperawatan Maharani Malang. Mata kuliah ini diberikan pada semester pertama jurusan Keperawatan Maharani Malang untuk dapat meningkatkan dan mendorong siswa untuk menggunakan buku teks kedokteran bahasa Inggris dalam memperoleh lebih banyak informasi tentang teori medis, karena semua buku panduan ditulis dalam bahasa Inggris. Tujuan dari penelitian ini adalah untuk menjawab langsung masalah utama penelitian, "Apakah siswa yang diajar dengan teknik scanning dan skimming memiliki kemampuan membaca yang lebih baik daripada mereka yang diajar dengan yang konvensional. Populasi penelitian adalah mahasiswa semester pertama Jurusan Perawat Maharani Malang yang mengambil mata kuliah Bahasa Inggris sebagai mata pelajaran wajib pada tahun ajaran 2014/2015. Karena hanya ada 70 siswa, penelitian ini tidak menggunakan prosedur pengambilan sampel. Ke 70 siswa tersebut digunakan sebagai kelompok eksperimen dan kelompok kontrol juga. Siswa dipisahkan secara acak dan menghasilkan 35 siswa sebagai kelompok kontrol dan 35 siswa sebagai kelompok eksperimen. Sebelum percobaan dilakukan, pretest diberikan kepada kedua kelompok. Setelah hasil tes, perawatan dimulai. Kelompok eksperimen diajarkan dengan menggunakan scanning dan skimming dan kelompok kontrol diajarkan dengan menggunakan teknik konvensional. Penelitian ini dilakukan dalam 16 pertemuan, Penelitian dimulai dari 1 Juni hingga 10 September 2017. Pada akhir penelitian, test terakhir diberikan untuk melihat efek dari dua teknik terhadap kemampuan membaca siswa. pemahaman apakah secara literal atau inferensial. T-test digunakan untuk mengukur dan untuk melihat efek dari teknik scanning dan skimming dan teknik konvensional untuk kemampuan membaca pemahaman siswa. Berdasarkan hasil analisis, ditemukan bahwa kemampuan yang berbeda secara signifikan dalam pemahaman membaca umum diperoleh. Nilai T-test yang diperoleh untuk pemahaman membaca umum adalah 4,01 sedangkan nilai kritis t pada $p<.05$ tingkat signifikansi dari one tailed adalah 1,671 $(d f=60)$. Dari perhitungan T-test, dapat disimpulkan bahwa siswa dalam kelompok eksperimen memiliki kemampuan yang lebih baik daripada mereka dalam kelompok kontrol dan teknik skimming lebih efektif daripada teknik konvensional. Dengan demikian, ditemukan teknik scanning dan skimming lebih efektif dalam membimbing siswa untuk mencapai hasil yang lebih baik daripada teknik konvensional, itu sebabnya penting bagi guru bahasa Inggris menggunakan teknik scanning dan skimming dalam membimbing. siswa mereka untuk belajar pemahaman bacaan dalam bahasa Inggris.
\end{abstract}

Katakunci: Teknik Scanning dan Skimming, meningkatkan kemampuan siswa

Reading is important skill in learning language. Harris and Smith (1986) argue that reading is the intellectual and emotional perception of a printed message. The success of failure in understanding written materials or reading text is dependent upon some factors. These factors may be classified into three categories: reader, textual and instructional. The success of failure in understanding written materials is dependent upon many factors. These factors may be classified into three categories: reader, textual and instructional.
First, category is readers 'psychological factors such as attitudes, interests, motivation, and habits. These factors are interrelated in the sense that a reader's personal attitude toward a certain reading topic determines his interest in reading it. Negative attitude results in poor interest and positive attitude results in good interest

In addition to the psychological condition within the reader, his cognitive abilities and general intellectual skills also affect comprehension in reading. They include abilities 
to decode, to recognize inductive sequences of ideas leading to a conclusion, to apply deductively a principle to new situation; and to recognize cause-effect, comparison, contrast, and other idea relationships.

Moreover, memory plays an important role in reading comprehension. The reader must recall what he reads as well as his own experiences and other relevant readings. (Olson and Dilner, 1982; Turner in Alexander, 1988). The reader's linguistics knowledge, such as knowledge of vocabulary and syntactic structure, also affects comprehension in reading. Therefore, unfamiliar with the words and difficult structure presented by the author of the text cannot obstruct the reader's comprehension. (Nuttal, 1982).

Finally, comprehension in reading is also affected by the reading strategy, reading rate, and concentration in reading. Different reading tasks and different reading selection requires different reading strategies and different reading rate. During reading, concentration is badly needed (Turner in Alexander, 1988; Harris and Sipay, 1980).

Second, the reading selection itself cannot be a cause of poor comprehension. Under the category of textual factors are difficulty of vocabulary items, complexity of structure, the length of the text and the cohesiveness of the text. Harris and Sipay (1980) suggest that the text selected for reading instruction be one that creates a desire to read and help individually find pleasurable recreation in reading. These conditions in part will be fulfilled if the reading selections are suitable to the student's level both in terms of their vocabulary contents and in terms of structural complexity. In addition, the length of the text should be appropriate to the student (Turner and Alexander, 1988). The teacher has to be very careful in selecting reading material. It should be selected in accordance with the student's age, reading ability, experiential background, and general intellectual skills. If it is too easy, the student will learn nothing, conversely, if it is too difficult, they will get frustrated. Therefore, Krashen's theory of input Hypotheses need considering. The theory says that if an acquirer is at stage or level I, the inputs she or he understands should contain $I+1$. This means that the language that the students are exposed to should be just far enough beyond their current competence that they can understand most of it but still find progress challenging. In other words, the instructional material should neither be beyond their reach that they are overwhelmed nor so close to their current stage that they find it no challenge at all. Moreover cohesiveness, of the text also influences comprehension (Turner in Alexander, 1988). Cohesion is short of intellectual "glue" that gives a piece of reading material unity and thrush in the mind of reader. Among the quality contributing to the cohesion are content organization, paragraph and sentence structure, idea development, and consistency of vocabulary use.

Finally, poor reading comprehension ability may also be due to poor training or instruction. Within this category falls two sub categories: inadequate instruction and improper instruction. Included in subcategory of inadequate instruction is lack of reading skill instruction. This may be due the fact that the teacher's program does not reach particular students. Overcrowded classroom is one explanation of this or too wide a range of students' prior reading ability in one classroom is another. Frequent changing of teachers is another causes of inadequate instruction that most teachers mention first is the cutting down of the time in which they can teach by needless interruption and special activities.

The other subcategory instructional cause of poor reading ability of the students is proper instruction. This may be due to reason as, first, an untrained teacher. Teaching reading requires more than just having the students read page by page. That is why, it should be handled by professional teachers. Moreover, unsystematic program may also be a reason for improper instruction. This is because there are certain sequences that should be followed in teaching the skills involved in learning to read. Next is the use of a single method of instruction. Since not all students will learn to read by any one particular method, the teacher who tries to teach all students by using exactly the same method is doomed to failure. Finally, inadequate undertakings of the students also create reading problems on the part of the students. Therefore, the teacher should know the characteristics of the 
students prior to the reading instruction. In addition, the progress of their reading ability should be followed and diagnoses should be made if they meet reading problems. Adequate diagnosis is essential in a successful reading instruction (Barbe in Karlin, 1969).

From reading they can enrich their view improve their experience and add their creativity, reading is considered as one of the most important skill in the school program. The teacher has to know some possible skills or technique that can increase students reading capability. To improve the student's skill in reading comprehension, technique of scanning and skimming need to be taught effectively to increase the speed of comprehending the text for the students. According to Smith and Johnson (2003:402) good scanning technique teaches are follow: a) Have all the facts or pieces of information you find clearly in mind. This will help you to find others as you are looking or a particular one. b) Start of the beginning of the selection and let your eyes sweep across and down page. Look for keywords that let you know what you are scanning for maybe nearby. Running your index finger down the middle of each page as you can scan may help you not to miss any lines of print. c) When you locate a key word or words, read around it or them to see if the information you were scanning for is there.

According to Nuttal (1987:34), skimming is glancing through a text to determine its gist. In line with this Callahan (1982: 254) states that skimming another rapid from reading, is used to survey the content of book, chapter or article, for such purposes as getting the heart or the gist of the material its general structure or plan, the points of view or facts bearing on a particular program or the eyes seems to float down the page, lighting the main ideas, or significance phrase or keywords. While Based on Mc.Neill (1992:48) that active reader seek printed material in order to meet variety of needs. And Nuttal (1988:34) says that skimming is useful skills. In reading, he adds that is enables the reader to select the text or the portions of text, there are worth spending time on. This clearly show the importance of skimming by skimming a reader can read various kind of text to get variety of needs in a limited time.

Based on the statement above it is clear that the use skimming and scanning are very important to be taught to the nursing studentsto improve their reading comprehension skills. English in Indonesia as foreign language in which it is hard to be mastered by nursing student who face the instructional material in form of text or text book in English. Through effective reading technique such as skimming and scanning, they can have good reading comprehension speed. Having a good reading speed, they can cope with the difficulty of mastering the English text book they use everyday

According to the description above it is important to conduct research to know the ability of 1st semester of the nursing students of College of Health Science Maharani Malang each Java Indonesia the academic year of 2014/ 2015.

The presents study is intended to see the effectiveness of scanning and skimming in improving reading comprehension course compared to conventional technique.

The researcher assumes that students who are taught using the scanning and skimming technique have better capability in reading comprehension skill than those who are taught by using the conventional technique.

\section{METHOD}

The research design employed in the study is Two Groups, Pretest and Post test Design. The subjects are grouped in such way that two equal group could be obtained, then a pretest is administered to ensure that the two groups remained equal. The research design is illustrated in following figure:

\begin{tabular}{|l|l|l|l|}
\hline Group & Pretest & Treatment & Posttest \\
\hline A & $\mathrm{Y}_{1}$ & $\mathrm{X}$ & $\mathrm{Y}_{2}$ \\
\hline B & $\mathrm{Y}_{1}$ & - & $\mathrm{Y}_{2}$ \\
\hline
\end{tabular}

The figure shows that both the protest and the posttest are administered. The administration of the pretest is just to prove whether the experimental group and the control group really have more or less equal initial reading comprehension ability. Therefore, the result of the pretest is analyzed by using a $\mathrm{T}$ - test to see the significance of the difference between the two means. 


\begin{tabular}{|l|l|l|l|}
\hline & & $\begin{array}{l}\text { INDEPENDENT VARIABLE (Teaching } \\
\text { Technique) }\end{array}$ \\
\hline & $\begin{array}{l}\text { Scanning } \\
\text { skimming } \\
\text { Technique } \\
(\mathrm{A})\end{array}$ & $\begin{array}{l}\text { Conventional } \\
\text { Technique } \\
(\mathrm{B})\end{array}$ \\
\hline $\begin{array}{l}\text { DEPENDENT } \\
\text { VARIABLE }\end{array}$ & $\begin{array}{l}\text { Reading } \\
\text { Comprehension(1) }\end{array}$ & $\mathrm{Y}_{\mathrm{A} 1}$ & $\mathrm{Y}_{\mathrm{B} 1}$ \\
\hline
\end{tabular}

\section{Population and Sample}

The target population to which the result of the present study could be expected to cover is the first semester students of for nursing student's collage of health science Maharani Malang. This is under an assumption that those students have many features in common. They have got Basic English education or general English while in the first semester (two credit semester system). They have the same Basic English or general English education.

The accessible populations are the students for nursing student's collage of health science Maharani Malang. For nursing students collage of health science Maharani Malang. The first semester of the 2014/2015 academic year.
The number of the accessible population is relatively small; all of the available students are taken as the subjects of the study. Therefore, no sampling design is employed. Rather, those 70 students are assigned to either the experimental group or the control group by random assignment. The procedure of random assignment resulted in a composition that the experimental group consists of 35 students, while the control group 35 students.

When the pretest was administered, 35students in the experimental group and 35 students in the control group attended the class. It means in the process of treatment were attended by full population

\section{FINDINGS}

As it was implied in the research design the process of data gathering of this study could be classified into 3 phases: pre-testing, treatment, and post testing

The pretest administration was conducted on June 1, 2017 and 35 students in experimental group and 35 students in the control group participated in this test. The test material used for the pretest was Reading For Nurse and Midwifery. The time allocation provided for the subjects to complete the test was 90 minutes.

The data obtained from the pretest were computed to find their mean $(\overline{\mathrm{X}})$ and standard deviation (SD). The result of the computation was summarized as follows

\begin{tabular}{|c|c|c|c|c|}
\hline \multicolumn{5}{|l|}{ Group } \\
\hline \multicolumn{2}{|c|}{ Experimental Group } & \multicolumn{3}{|c|}{ Control Group } \\
\hline $\mathrm{N}$ & 35 & $\mathrm{~N}$ & $=$ & 35 \\
\hline EX & 1939 & EX & $=$ & 2015 \\
\hline$\overline{\mathrm{X}}$ & 55.4 & $\overline{\mathrm{X}}$ & $=$ & 57.6 \\
\hline$\sum X^{2}$ & $=109625$ & $\sum \mathrm{X}^{2}$ & $=$ & 11879 \\
\hline SD & $=7.93$ & $\mathrm{SD}$ & $=$ & .85 \\
\hline
\end{tabular}

The table shows that the mean score of the experimental group is 55.4 while the mean score of the control group is 57.6 Furthermore, the standard deviation of the experimental group is 7.93 whereas the standard deviation of the control group is 8.85

These two sets of figures were then used for computing the standard Error of the Different between Mean ( $\mathrm{SD}_{\mathrm{x}}$ ) by using a formula as follows

$\mathrm{SDX}=\sqrt{\frac{N_{1} S D_{1}^{2}+N_{2} S D_{2}^{2}}{N_{1}+N_{2}-2}+\left(\frac{1}{N_{1}}+\frac{1}{N_{2}}\right)}$

The calculation found that the $\mathrm{SD}_{\mathrm{x}}$ was 2.04This figure was then used to computethe value of $t$ using a $t$ test. To do this, the formula used is:

$\mathrm{t}=\frac{\overline{\mathrm{X}}_{1}-\overline{\mathrm{X}}_{2}-0}{\mathrm{SD}_{\mathrm{x}}}$ 
The application of the formula resulted in a $t$ value of 1.06 ( the computation for $t$-test, see appendix 6 ) When this $t$ value was tested by comparing to the critical value of $\mathbf{t}$ at 0.05 level of significance for one tailed test, it was found that the obtained $t$ value was smaller than the critical value of $\mathbf{t}$ as it was 1.671 (d.f $=68$ ).

Therefore, it was concluded the subjects in the experimental group and those in the control group were not significantly different reading ability prior to the treatment. In other words, statistically the subjects in the two groups had equal reading ability prior to the experimental treatment.

The final data analysis is done in order to get the answers to the research questions of this study. To find the answer to the major problem and sub problem of the present research, a t-test was employed. The $t$ test was employed three times in which the first was to find the significance of difference of the subjects' scores at the reading comprehension and the second was to find the significance of difference of the subjects' scores at the literal level. The third was to find the significance of difference of the subjects scores at the inferential level. The significance level used was $p=.05$

Based on the research finding in the present study, it is found that the statistic computation from the post test supports the hypothesis, and the students taught with scanning and skimming has better scores in general reading comprehension than those who taught with the conventional one. This finding means that the Null hypothesis is rejected and the working hypothesis is accepted. The finding of the present study also shows that the scanning and skimming technique of teaching reading comprehension is more effective than the conventional technique for improving the student's reading comprehension.

The result of computation of students' scores on the reading comprehension is summarized in the following table;

Figure IVSummary of Computation for t-test for reading comprehension

\begin{tabular}{|c|c|c|c|}
\hline GROUP & & & \\
\hline Experimental G & & Control Group & \\
\hline & $=35$ & $\mathrm{~N}$ & $=35$ \\
\hline$\sum \mathrm{X}$ & $=2497$ & $\sum X$ & $=2295$ \\
\hline$\overline{\bar{X}}$ & $=71.3$ & $\overline{\mathrm{X}}$ & $=65.6$ \\
\hline$\sum X^{2}$ & $=179645$ & $\sum X^{2}$ & $=151331$ \\
\hline SD & $=7$ & SD & $=4.5$ \\
\hline
\end{tabular}

The table shows that the mean score of the experimental group is 71.3 while that of the control group is 65.6. Moreover, the standard deviation of the students' score in the experimental group is 7 while that of student's scores in the control group is 4.5 .

\section{DISCUSSION}

Before the treatment was done, the hypothesis that has been predicted that null hypothesis is rejected. After the treatment of the students is done beginning with choosing the number of the population as many as 70 students and then the students are separated into two groups, they are group A and group B, each groups contains 35 students, and both are given pre-test, the result of the test from the two groups is being analyzed and the result show both of them tend to have the similar capability. The next steps of the answering the hypothesis is to give treatment to one of group and it is called Group A and group B as a control group. The treatment was given for 4 months and final steps of the treatment are given posh test and the result analysis of the t-test as presented in setting 4.1 results in a finding that in general the students taught with the scanning and skimming technique get better score in reading comprehension test than those taught with the conventional technique. As a result, the null hypothesis is rejected, while the working hypothesis is accepted. This indicates that the present study proves that the scanning and skimming technique of teaching reading comprehension develops students' comprehension skill more effectively than the conventional technique. The summary as follows; 
Figure VSummary of Data Analysis for Hypothesis Testing

\begin{tabular}{|l|l|l|l|l|l|l|l|}
\hline $\begin{array}{l}\text { N } \\
\text { o }\end{array}$ & $\begin{array}{l}\text { Dependent variable/ } \\
\text { Group }\end{array}$ & $\mathbf{X}$ & $\mathbf{S d}$ & $\mathbf{S D}_{\mathbf{x}}$ & t-value & $\begin{array}{l}\text { t- } \\
\text { critical }\end{array}$ & $\begin{array}{l}\text { Remar } \\
\mathbf{k}\end{array}$ \\
\hline 1 & $\begin{array}{l}\text { General comprehension } \\
\text {-Experimental Group } \\
\text {-Control group }\end{array}$ & $\begin{array}{l}71.3 \\
65.6\end{array}$ & $\begin{array}{l}7 \\
4.5\end{array}$ & 1.42 & 4.01 & 1.671 & $\begin{array}{l}\text { Ho is } \\
\text { rejected }\end{array}$ \\
\hline
\end{tabular}

\section{CONCLUSION}

Based on the result of the data analyses and the discussion of the finding, some conclusion can be drawn. First, the Scanning and skimming technique of teaching reading comprehension and the conventional technique of teaching reading comprehension have different impact on students' comprehension achievement. In this case, the students who are taught with scanning and skimming technique tend to have better reading achievement than those who are taught with the conventional technique.

Second, the scanning and skimming technique is more effective than the conventional technique. It means that the students who are taught with scanning and skimming technique tend to have better literal and inferential comprehension achievement than those taught with the conventional technique. In short, the scanning and skimming technique is in general more effective than the conventional one in facilitating student's learning to read.

\section{SUGGESTION}

In reference to the findings, some recommendations are made for reading instruction and future studies. The first recommendation is objected to classroom teachers of reading, as they are facilitator in learning process. The scanning and skimming technique is recommended to be used as a technique of teaching reading comprehension to non- English department as well as English department student. In order that the application of scanning and skimming techniques runs well in the classroom practice, the reading teachers who plan to use it are recommended that they consider to select the instructional material. It has to be appropriate for the student's level in terms of its vocabulary, syntactic complexity, and topic familiarity because this technique of teaching will not work if the students encounter too difficult passage.
The second recommendation goes to further studies. Relevant to the finding, suggestions for further research are made as follows:

(1) The present study uses only students of nonEnglish department of private University as the target population and the students of for nursing students collage of health science Maharani Malang. As the accessible population. Further studies are suggested to be conducted to students of English department.

(2) The present study is limited only to literal and inferential levels of comprehension. It is suggested that future study be conducted to include the evaluation level of comprehension

(3) The present study is limited only to students taking reading comprehension in intermediate level. Therefore, similar studies are recommended to be conducted to the students of advanced level. The study may include more accessible population with larger target population.

\section{RECOMMENDATION}

In reference to the findings, some recommendations are made for reading instruction and future studies. The first recommendation is objected to classroom teachers of reading, as they are facilitators in learning process. The scanning and skimming technique is recommended to be used as technique of teaching reading comprehension to non English department as well as English department students. In order that application of scanning and skimming technique runs well in the classroom practice, the reading teachers who plan to use it are recommended that they consider select the instructional material. It has to be appropriate for the students level in terms of its vocabulary, syntactic complexity and topic familiarity because this technique of teaching will not work if the students encounter too difficult passage. 
The second recommendation goes to further studies. Relevant to the findings, suggestions for further research are made as follows:

1. The present study uses only students of nonEnglish department of private University as the target population and the students of for nursing students collage of health science Maharani Malang. As the accessible population. Further studies are suggested to be conducted to students of English department.

2. The present study is limited only to literal and inferential levels of comprehension.

3. The present study is limited only to students taking reading comprehension in intermediate level. Therefore, similar studies are recommended to be conducted to the students of advanced level. The study may include more accessible population with larger target population.

\section{REFERENCES}

Alexander, J. Estill. 1988. Teaching English. Boston: Scott, Forestman and Company. Anastasia, A. 1976.Psychological Testing New York: Macmillan Publishing Co, Inc.
Bachman, Lyle F. 1990. Fundamental Consideration in Language Testing Oxford: Oxford University Press.

Chaudron, C.1988. Second Language Class Room, research on Teaching and Learning Cambridge: Cambridge University Press.

Harris, Albert J, and Sipay E.R 1980. How to increase Reading Ability, NewYork : Longman.

Kartin, R. 1984.Teaching Reading in High School Improving Reading in Content Area. New York: Harper \&Roe, Publisher

Krashen, S.D. 1985. The Input Hypothesis: Issue and Implication. London: Longman.

Olson, Joane P and Diller, Martha, H. Leanring to Teach Reading at ElementarySchool New York: Macmillan Publishing Co, Inc

Pietro, R.J.D. 1979. Strategy Interaction Learning Through Scenario. Cambridge: Cambridge University Press.

Rivers, W.M. 1987 Interactive Language Teaching, Cambridge: Cambridge University Press.

Singer, H, Ruddel R.B. 1985. Theoretical Model and Process of Reading ( Third Edition). New Jersey: International Reading Association, Inc. 
24\| Chindy Hanggara R. I. , The Effectiveness Of Scanning ..... 